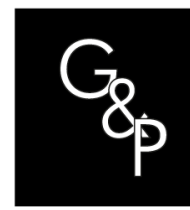

\title{
Lean waste analysis in light of principles of public administration: a study of an IFES academic project submission process
}

\author{
Análise de desperdícios a luz dos princípios da administração \\ pública: um estudo em um processo de submissão de projetos \\ acadêmicos de uma IFES
}

\begin{abstract}
Rosaneide Maria Garcia da Silva Ubarana ${ }^{1}$ (), Thiago de Oliveira ${ }^{1}$ (), André Morais Gurgel ${ }^{1}$ (), Josué Vitor de Medeiros Júnior ${ }^{1}$ (D)

${ }^{1}$ Universidade Federal do Rio Grande do Norte - UFRN, Reitoria - Secretaria de Gestão de Projetos, Lagoa Nova, Natal, RN, Brasil. E-mail: rosanegarcia@hotmail.com; thiago.oliveira.adm@outlook.com; tiagodoliveira1@gmail.com; andregurgel@reitoria.ufrn.br; andmgurgel@gmail.com; josuevitor@reitoria.ufrn.br; josuevitor16@gmail.com
\end{abstract}

How to cite: Ubarana, R. M. G. S., Oliveira, T., Gurgel, A. M., \& Medeiros Júnior, J. V. (2021). Lean waste analysis in light of principles of public administration: a study of an IFES academic project submission process. Gestão \& Produção, 28(3), e5314. https://doi.org/10.1590/1806-9649-2021v28e5314.

\begin{abstract}
The New Public Administration (NPA), guided by the Principles of Public Administration (PPA), has incorporated several approaches to promote more effective management. Among these is the lean perspective, focused on eliminating waste and improving organizational processes. Thus, the present study aims to analyze the relationship between types of waste and PPA. To that end, the investigation uses data triangulation from the focus group, and workshop and participant observation as methodological approaches, demonstrating that process waste can compromise PPA. However, adhering to the principles can benefits process execution by reducing rework, for example. This perception contradicts common sense, which presupposes increased bureaucracy to address legal issues or constitutional principles. Thus, lean waste analysis according to PPA may prove to be relevant and a new perspective for improving organizational processes in public management.
\end{abstract}

Keywords: Principles of Public Administration; Lean Waste; Process; Relationship.

Resumo: A Nova Administração Pública (NAP), orientada pelos Princípios da Administração Pública (PAP), incorporou diversas abordagens para promover uma gestão mais eficaz. Entre elas está a perspectiva enxuta, com foco na eliminação de desperdícios e na melhoria dos processos organizacionais. Assim, o presente estudo tem como objetivo analisar a relação entre tipos de Desperdícios e PAPs. Para tanto, a investigação utiliza a triangulação de dados do grupo focal, oficina e observação participante como abordagens metodológicas, demonstrando que os desperdícios do processo podem comprometer os PAPs. No entanto, a adesão aos princípios pode beneficiar a execução do processo, reduzindo o retrabalho, por exemplo. Essa percepção contraria o senso comum, que pressupõe aumento da burocracia para tratar de questões jurídicas ou princípios constitucionais. Dessa forma, a análise de desperdícios enxutos segundo os PAPs pode se mostrar relevante e uma nova perspectiva de melhoria dos processos organizacionais na gestão pública.

Palavras-chave: Princípios da Administração Pública; Desperdícios Lean; Processo; Relacionamento.

Received Jan. 25, 2019 - Accepted Jul. 8, 2019

Financial support: None.

This is an Open Access article distributed under the terms of the Creative Commons Attribution License, which permits unrestricted use, distribution, and reproduction in any medium, provided the original work is properly cited. 


\section{Introduction}

In the context of Brazilian public administration (PA), the 1990s marked a milestone in the search for efficient public services, via administrative reform and Constitutional Amendment 19/1998, which introduced the Principle of Efficiency in article 37 of the 1988 Federal Constitution (Pereira, 1996; Brasil, 1988).

Based on this amendment, and in addition to being guided by the principles of legality, impersonality, morality and publicity, PA began to focus on efficiency and was restructured to improve service quality (Di Pietro, 2015).

However, although the law stipulates efficiency in public service, there are no guidelines on how to achieve it. Thus, over the years, public institutions have incorporated some of the private sector management practices in their quest for better performance (Turati \& Musetti, 2006; Lima \& Leite, 2011).

One of these is the lean approach, whose main purpose is to enhance work flows and eliminate waste in administrative areas (Turati \& Musetti, 2006).

In general, the lean approach is considered a synonym of streamlined production, conceived by the Toyota Motor Company in the mid-1950s based on the following principles: focusing on the client, process flow and eliminating waste and activities that cause losses and do not add value (Womack et al., 2004; McManus, 2005; Liker, 2007; Graban, 2013; Gonçalves et al., 2015; Ohno, 2015).

Moreover, lean principles have supported management and improved public organizations by identifying and eliminating waste and cost along the value network, as well as enhancing work process performance (Lima \& Leite, 2011; Turati \& Musetti, 2006).

The results of these studies demonstrate that lean concepts can improve public management performance, promoting greater user satisfaction and making them faster and more efficient (Turati \& Musetti, 2006).

A critical factor in lean is the reduction and possible elimination of process waste. Thus, waste is everything that does not add value to the client and/or process (Liker, 2007).

As such, it is important that the process of identifying, eliminating or minimizing waste be adapted to the public context, primarily in relation to principles of public administration (PPA), which should be developed according to PPA because contravening them is a serious act against an entire system and subverts their fundamental values (Mello, 2011).

Federal institutions of higher learning are an example of this reality, organized as a special regime autarchy and affiliated with the Ministry of Education (MEC), which has been notably perfecting its management practices.

Since 2006, a particular sector of these institutions has been executing an organizational improvement project, more specifically in the academic projects submission process. Procedural processes sometimes fail to meet the needs of their users.

However, given that the entire administrative act should be guided by PPA and that their processes should obey the principles, the present study attempts to answer the following question: what is the relationship between identifying waste categorized according to lean and the principles of public administration?

Thus, the aim of the present study is to present an analysis of the relationships between lean wastes, identified in the flow of a particular process in a public learning institution and the PPA.

The follow sections present the concepts of public administration and their principles; a brief contextualization of the lean approach and its concepts, the methodology that underpins this study; the results of the relationships between lean waste and the PPA; as well as final considerations, limitations and perspectives for future research. 


\section{Public administration and its basic principles}

In general, the hermeneutics of PA are broad, encompassing legislation and execution, in addition to the administration function per se and the function of government (Di Pietro, 2015).

Thus, PA can be viewed from formal, material and operational perspectives. The formal perspective is a set of entities that execute government policies; the material perspective considers public functions; and operational perspectives contain performance-related aspects, as well as the legal and technical procedures of state services or others it is responsible for (Pereira, 2010).

According to Mello (2011), PA must proceed honestly and in good faith, and is prohibited from engaging in any act that corrupts its principles and prevents citizens from exercising their rights.

As such, unlike private enterprise, PA can only act in accordance with the law and not autonomously. This makes the principle of legality a cornerstone for other principles, despite there being no hierarchy between them, since it limits all administrative acts to the law, whether they are associated or discretionary (Gasparini, 2012).

Thus, in addition to acting lawfully, public administrators must also act impersonally and equitably, refraining from any particular preference and always focusing on public interest. In this respect, Gasparini (2012) states that administrative activity should target all citizens, with no discrimination whatsoever.

Miragem (2013) adds that the forceful aspect of impersonality is its link to public interest, which is a type of rejection of partial, group or individual interests.

According to Gasparini (2012), PA activities must comply not only with the law, but morality itself, because not everything that is legal is honest. This assertion is pertinent because principles of public administration complement one another, meaning an administrative act must therefore be both legal and moral.

In addition, given PA is aimed at the public interest, the principle of publicity makes the diffusion of acts, contracts and other direct and indirect PA instruments mandatory, in order to know, control and initiate their effects (Gasparini, 2012).

The principle of efficiency, created by Constitutional Amendment 19/1998, is a milestone in public management because it stipulates greater productivity in the shortest time, and at the lowest cost possible. In other words, procrastination is never justified and may lead PA to compensate for losses caused by delays in a state initiative.

In this regard, the managerial public administration model seeks not only quality in public services to better meet the needs of its users, but effective solutions for budgetary and procedural problems, with lower costs and more efficient use of resources, that is, an outcome-oriented model (Abrucio, 2010).

\section{Lean}

The Toyota Production System (TPS), or streamlined production, is a work management philosophy whose mission is to meet the customer needs in the shortest time, with the highest quality and at the lowest possible cost, eliminating waste in the process flow and adding value to the entire supply chain (Liker, 2007).

The lean concept, derived from the TPS, is characterized as an essentially empirical method whose aim is to improve worker productivity with a strong emphasis on training, based on continuous improvement, also known as kaizen (Liker, 2007; Bekesas, 2012; Ohno, 2015). Thus, lean or streamlined production and TPS can be considered synonyms. 
Lean eventually expanded beyond manufacturing processes as other organizational structures implemented it (Graban, 2013), making it applicable in any organization, whether private or public (Cole, 2011).

Lean offices are administrative environments and industrial operations that have implemented the lean philosophy, using different methods and streamlining tools to reduce waste in administrative processes and settings (Landmann et al., 2009).

A number of national and international public organizations have adopted the lean concept in management and this emerging trend may favor a paradigm shift in PA, minimizing the politicized cycle and short-term pressures in this sector (Kadarova \& Demecko, 2016).

According to Gonçalves et al. (2015), lean is an interpretation of the streamlined manufacturing concepts of information flows that do not follow the flows of the process of physical assembly of products or materials.

However, it is important to underscore that a critical factor within the lean concept is waste reduction (or muda, the Japanese word for waste), which, in turn, is everything that does not add value to the customer and/or process (Liker, 2007).

Lean waste, according to McManus (2005), is presented in Table 1 below, using information as input:

Table 1. The Seven Wastes.

\begin{tabular}{|c|c|c|}
\hline Information Waste & Examples: & Causes \\
\hline Waiting & \multirow{3}{*}{ People waiting for information } & $\begin{array}{c}\text { - Lack of access to information } \\
\text { due to delay }\end{array}$ \\
\hline \multirow[t]{2}{*}{ Idle time } & & $\cdot$ Multiple approvals \\
\hline & & $\begin{array}{c}\text { Poor design or execution of } \\
\text { information generating } \\
\text { processes }\end{array}$ \\
\hline Inventory & \multirow{3}{*}{ Outdated/obsolete information } & · Lack of version control \\
\hline \multirow[t]{3}{*}{$\begin{array}{l}\text { Store of information that is not } \\
\text { used }\end{array}$} & & $\begin{array}{l}\text { - Lack of an adequate system } \\
\text { to update information (adding } \\
\text { the new and excluding the old) }\end{array}$ \\
\hline & & $\begin{array}{l}\text { - Inadequate archiving } \\
\text { standards or practices }\end{array}$ \\
\hline & "Just-in- case" information & $\begin{array}{l}\text { Extraction, processing and } \\
\text { filing of all data generated by } \\
\text { participants, with or without } \\
\text { identifying the specific use }\end{array}$ \\
\hline Excessive processing & Excessive/custom formatting & - Lack of standardization \\
\hline \multirow[t]{2}{*}{$\begin{array}{l}\text { Information processing beyond } \\
\text { requirements }\end{array}$} & \multirow[b]{2}{*}{ Numerous, fragmented reports } & - Low output quality \\
\hline & & $\begin{array}{c}\text { - Lack of understanding of user } \\
\text { needs regarding output } \\
\text { processes }\end{array}$ \\
\hline Overproduction & \multirow[b]{2}{*}{ Unnecessary details } & - Tendency to over-design \\
\hline \multirow[t]{2}{*}{$\begin{array}{l}\text { More information than } \\
\text { necessary }\end{array}$} & & More details than necessary \\
\hline & $\begin{array}{l}\text { "Pushing" and not "pulling" data } \\
\text { and information }\end{array}$ & - Non-controlled process \\
\hline Transportation & $\begin{array}{l}\text { Information handled by several } \\
\text { people before reaching the user }\end{array}$ & $\begin{array}{l}\text { - Lack of direct access due to } \\
\text { IT system limits, organizational } \\
\text { inefficiency, knowledge } \\
\text { hoarding, security issues }\end{array}$ \\
\hline
\end{tabular}


Table 1. Continued...

\begin{tabular}{|c|c|c|}
\hline $\begin{array}{l}\text { Unnecessary movement of } \\
\text { information between people }\end{array}$ & \multirow{3}{*}{ Data reformatting or reentry } & $\begin{array}{c}\text { Incompatible information } \\
\text { types (drawings vs. digital } \\
\text { descriptions) }\end{array}$ \\
\hline & & $\begin{array}{c}\text { Incompatible software } \\
\text { systems or tools }\end{array}$ \\
\hline & & $\begin{array}{l}\text { Lack of availability, knowledge } \\
\text { or training in conversion and } \\
\text { linking systems }\end{array}$ \\
\hline Unnecessary motion & \multirow{2}{*}{$\begin{array}{l}\text { Walking to obtained information } \\
\text { or printed material }\end{array}$} & $\begin{array}{c}\text { - Lack of distributed, direct } \\
\text { access }\end{array}$ \\
\hline $\begin{array}{l}\text { Unnecessary human } \\
\text { movement }\end{array}$ & & - Lack of online access \\
\hline & \multirow{3}{*}{$\begin{array}{l}\text { Excessive digitizing, mouse } \\
\text { operations }\end{array}$} & - Lack of training \\
\hline & & $\begin{array}{l}\text { - Poorly designed user } \\
\text { interfaces }\end{array}$ \\
\hline & & - Incompatible software suites \\
\hline & \multirow{2}{*}{$\begin{array}{c}\text { Poor physical organization or } \\
\text { arrangement }\end{array}$} & $\begin{array}{l}\cdot \text { Team members not co- } \\
\text { located }\end{array}$ \\
\hline & & $\begin{array}{l}\text {. Organizational structure } \\
\text { inhibits correct team formation }\end{array}$ \\
\hline Defects & \multirow[b]{2}{*}{ Errors in data reporting } & $\cdot$ Human error \\
\hline \multirow[t]{2}{*}{$\begin{array}{l}\text { Erroneous data and } \\
\text { information }\end{array}$} & & $\begin{array}{c}\text { Poorly designed input } \\
\text { templates }\end{array}$ \\
\hline & $\begin{array}{c}\text { Errors in information provided to } \\
\text { customers }\end{array}$ & $\begin{array}{l}\text { - Lack of a disciplined reviews, } \\
\text { tests, verification }\end{array}$ \\
\hline
\end{tabular}

SOURCE: McManus (2005).

In this respect, Graban (2013) presented a broader definition of waste, namely, that it is any problem that interferes in people's ability to perform their job efficiently or any activity that does not provide added value to the customer.

Identifying these activities and wastes is an important exercise in process management because it allows one to analyze whether activities with no added value are really necessary and can be eliminated to lower costs, improve the quality and productivity of services and raise customer satisfaction (Graban, 2013).

\section{Methodology}

Given the need for better understanding and interpretation on the part of researchers, this is a qualitative study of the phenomena related to the context and observed by participants in a natural environment (Sampieri et al., 2013; Flick, 2013; Santos, 2016).

The study is also descriptive from a results standpoint, since it sought information in order to obtain an in-depth understanding of the study setting, the relationship between the stakeholders and how the current process occurs, to then identify and analyze waste (Richardson, 2008).

The production and use of knowledge in a real study situation was also investigated (Thiollent, 2011; Vergara, 2015; Santos, 2016). The data collection process focused on identifying lean waste, which made it possible to achieve the other research objectives.

Data collection with triangulation was selected to reduce research inconsistencies and contradictions, using multiple reference points to achieve more valid and reliable results (Paiva et al., 2011). A focus group, workshop and participant observation were adopted (Flick, 2013; Sampieri et al., 2013; Vergara, 2015). 
Triangulation of data collection instruments was used throughout the project, constantly recording data and information from discourses, referrals and decisions in documents and audios that were later transcribed.

The focus group was held first, consisting of 23 project coordinators and analysts and encompassing the principles involved in the flow of the academic submission process, the general sample selection criterion used in the present study.

This first meeting was important in understanding the process and its scope, as well as the perception of its stakeholders and customers regarding its performance, problems and proposals for improvement. To collect and record data from the discourses, the meeting was audio recorded and participant observation was used to help understand the phenomenon under study (Sampieri et al., 2013).

Mapping concepts and process analysis were presented at the workshop, modeled and visually represented using BPMN (Business Process Model and Notation). It is important to underscore that participant observation was also used at this second meeting and data and information recorded.

The third phase involved a working meeting with the participants to identify and analyze waste in the previously mapped process flow. Thus, together with the focus group held in the first phase and participant observation, applied in the ensuing stages, it was possible to identify waste from the perspective of the stakeholders and customers.

Data collection concluded at the end of the meetings with participants, followed by data treatment and analysis. To that end, content analysis (CA) was used with QSR NVivo $®$ software, version 11.

CA involved three basic stages: prep-analysis, that is, the selection of material and procedures; exploration of the material, executing the procedures established in preanalysis, with audio transcription, coding and categorization; and data treatment and analysis, making associations and inferences to obtain the results of the study (Bardin, 2006; Richardson, 2008; Vergara, 2015).

The next step was to listen to the audio transcripts of the meetings with the study participants, and then read the transcribed materials to examine the content of the texts.

Coding and categorization followed initial analysis to better understand the meanings and narratives (Sampieri et al., 2013). This procedure involved sentence-by-sentence coding and, when necessary, paragraph by paragraph, of excerpts that fit into certain code categories.

After coding, the categories were analyzed for potential causal relationships, intervening and contextual conditions and interactions.

A total of 12 main categories were generated, via close-ended nodes in NVivo®, since preliminary definition of these categories was based on the theoretical construction of lean (McManus, 2005) and principles of public administration (Di Pietro, 2015; Mello, 2011; Gasparini, 2012; Miragem, 2013; Abrucio, 2010) (Sampieri et al., 2013). In other words, the nodes, or code categories, refer to the 7 wastes and 5 PPA.

In the material exploration phase, the audio transcripts were imported to NVivo® in Microsoft Word format, and the sentences and paragraphs (units of analysis) that mentioned any type of problem or waste in the process were selected. The units of analysis were refined and repetitions excluded, reaching the final number of wastes identified in the process (Table 1).

The chosen units of analysis from the waste categories created in the main nodes were inserted, according to the interpretation of the Lean Office concepts proposed by McManus (2005).

After the units of analysis were refined by waste, they were related to the PPA categories. Knowledge inference related to the topic was used to group each previously classified unit of analysis into its respective PPA category. 
This procedure was based on coding and information derived from analyzing the statements of participants involved in the theoretical framework of the previously mentioned principles. Thus, as soon as wastes and their effects on the process were identified, the statements were analyzed in an attempt to understand how these effects compromised the PPA, and which PPA were affected, associating waste categories with the theoretical constructs in terms of the principles (Vergara, 2015). This association is best interpreted in the results.

Two types of relationships were identified between the wastes and PPA: compliance, which seeks to achieve the principles and generally derives from legal necessity and damage, which are contrary to PPA guidelines. These relationships are identified in the participant discourses presented in the results to reinforce these assertions.

The methodological procedures are illustrated in Figure 1:

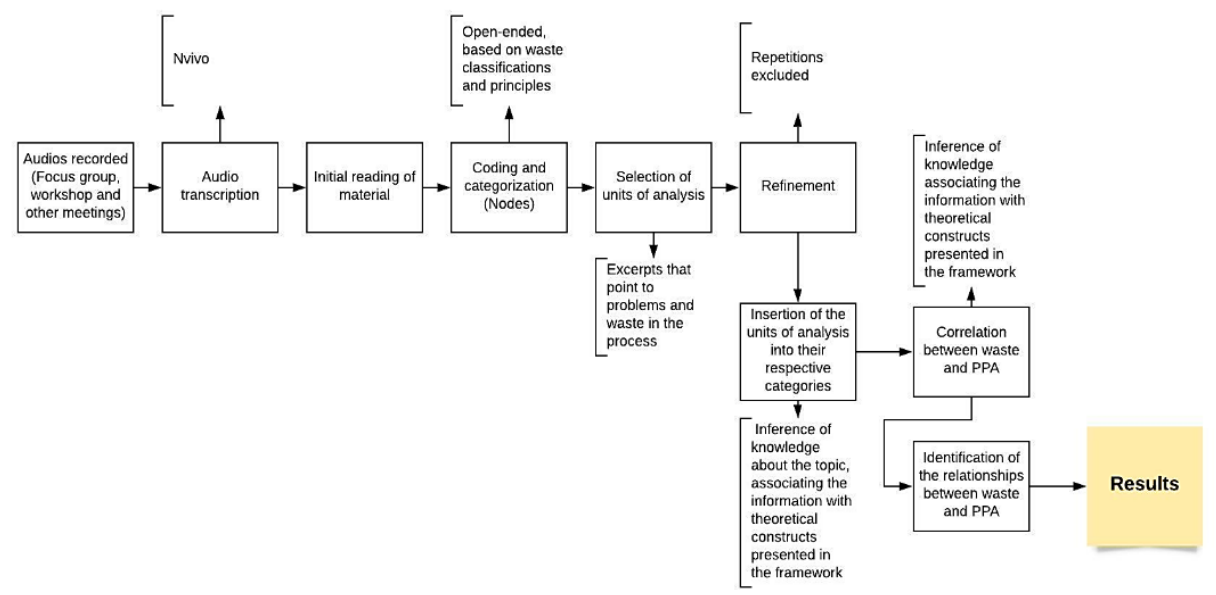

Figure 1. Methodological procedures. Source: The authors (2018).

Finally, this information was compiled and represented in diagrams in order to better visualize the results, demonstrating the relationship between waste and PPA in the process analyzed.

\section{Discussion and analysis of the results}

The process under analysis is the formal submission of academic projects whose product (output) is the signing of an academic contract, authorizing several projects submitted by research professors. These projects vary from specialized courses and research extension activities to scientific research in areas of knowledge that may lead to the concession of patents. The main stakeholders of the process are the project coordinator, department of the coordinator, department of agreements and contracts (C3), support foundation, faculty of planning (PROPLAN) and other IFES faculties.

The process was mapped and is presented in the Figure 2. 


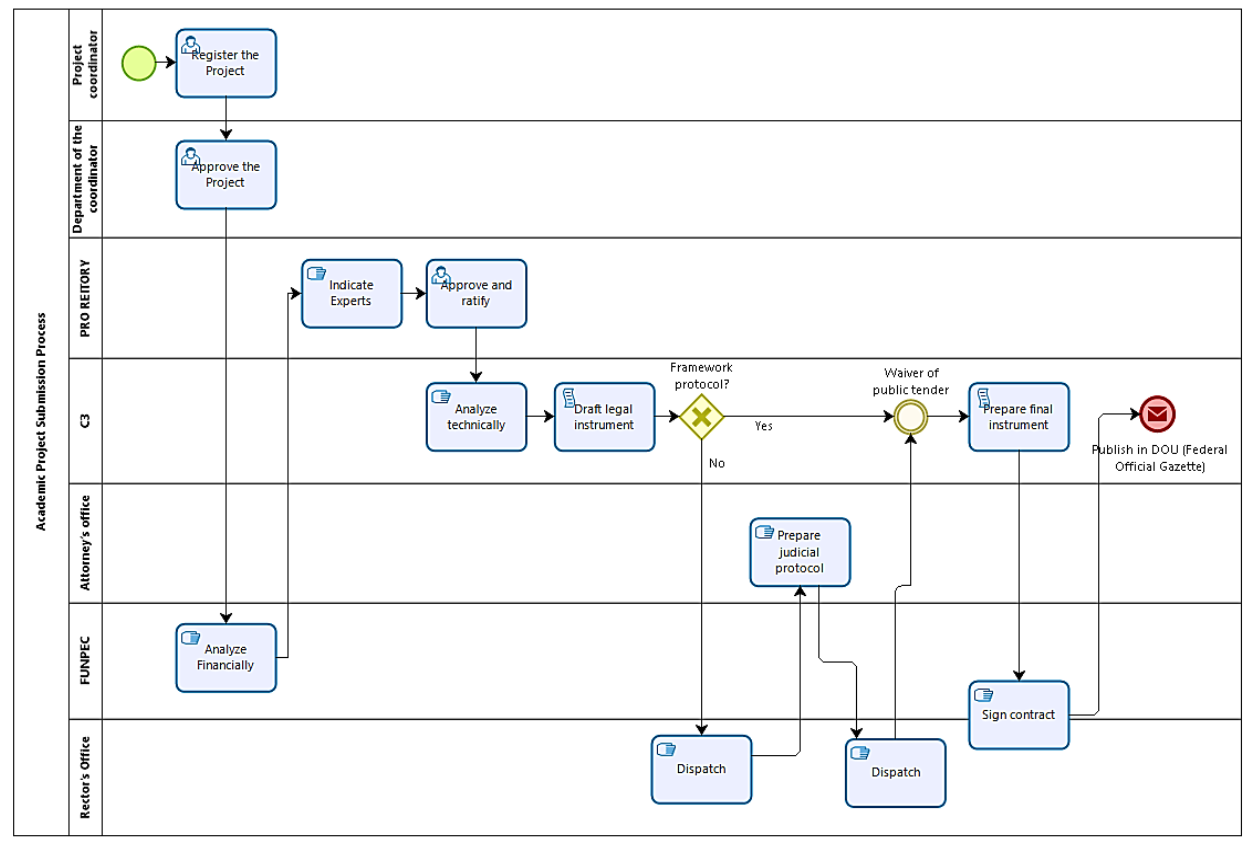

Figure 2. Academic Project Submission Process. Source: The authors (2018).

The present process was analyzed from the lean perspective and problems and bottlenecks in its flow were identified and converted into waste. Table 2 presents the wastes identified in the process and their quantification after data analysis

Table 2. identification of waste according to the Lean Office approach.

\begin{tabular}{|c|c|}
\hline Waste (McManus, 2005) & Amount \\
\hline Waiting & \multirow{2}{*}{16} \\
\hline Idle time due to unavailable information & \\
\hline Defects & \multirow{2}{*}{9} \\
\hline Erroneous data, information or reports & \\
\hline Unnecessary motion & \multirow[b]{2}{*}{6} \\
\hline $\begin{array}{c}\text { Unnecessary human movement (physical or user movement } \\
\text { between tools or system) }\end{array}$ & \\
\hline Transportation & \multirow[b]{2}{*}{2} \\
\hline $\begin{array}{c}\text { Unnecessary movement of information between people, } \\
\text { organization or systems }\end{array}$ & \\
\hline Excessive processing & \multirow{2}{*}{1} \\
\hline Information processing beyond requirements & \\
\hline Inventory & \multirow{2}{*}{1} \\
\hline Information that is unused or "work in progress" & \\
\hline Overproduction & \multirow{2}{*}{1} \\
\hline Producing and distributing more information than necessary & \\
\hline AMOUNT OF WASTE IDENTIFIED & 36 \\
\hline
\end{tabular}

Source: The authors (2018). 
A total of 36 sources of waste were identified in the process. Note that waiting is what most compromises the process, making it cumbersome. Similarly, defects, which are errors in information; transportation, which considers unnecessary movement of information between people and handoffs; and unnecessary motion, unnecessary human movement in process execution, are the next most frequent observed in analysis.

The Figure 3 presents the sources of waste in process flow, in relation to two or more activities, or in a series of activities.

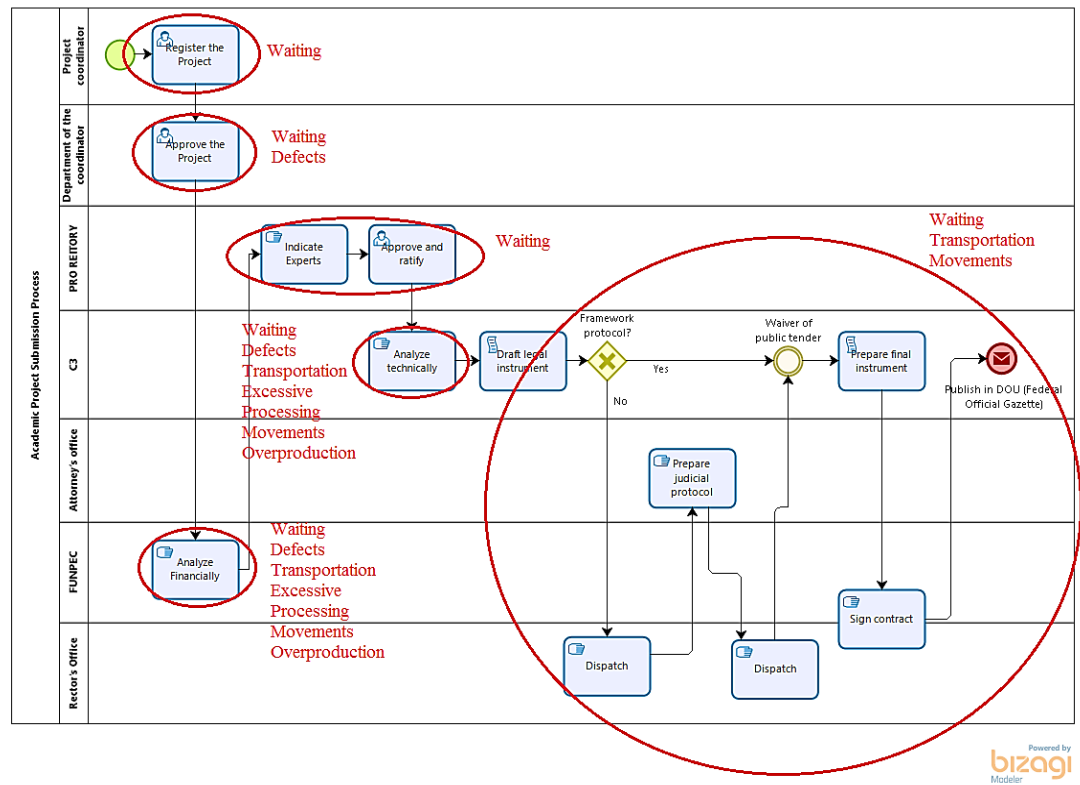

Figure 3. Identification of Process Waste. Source: The authors (2018).

Thus, all lean waste was investigated individually using data interpretation. The principles associated with each source of waste and the existing relationship were identified, starting with waiting waste, as shown in Figure 4.

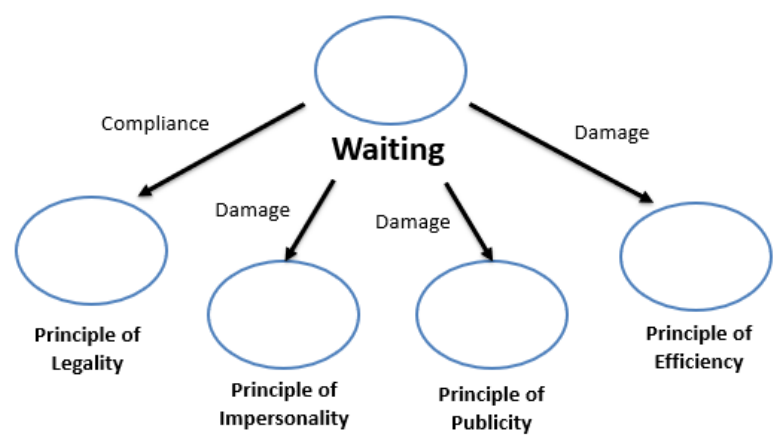

Figure 4. Nodes of the relationship between waiting waste and the PPA. Source: Research data (2018).

In this case, according to the concept of pure waste, waiting is what most affects the flow because it adds no value to the process (Liker, 2007). This includes people waiting 
for information, adjustments or progression to the next phase in the process, due to the need for project approval by multiple departments and information being generated far too soon, making it obsolete when used.

In addition, the registration process involves waiting for different documents in order to proceed with submission; project approval is delayed in the department in charge of this process, preventing submission from continuing; the office of the Vice President delays ratifying the protocol issued for the project; the process reaches the technical analysis sector without the necessary instructions, causing further delay until the situations is rectified. This is exemplified by individual $X$ :

...sometimes the office of the Vice President ... is slow to indicate experts, the application arrives in the department, the boss doesn't look at it and it stays there for three, five days...

(C3 and FUNPEC workers at a process analysis meeting)

...Sometimes the record doesn't arrive at the department...

(C3 and FUNPEC workers at a process analysis meeting)

...Sometimes professors don't deliver a declaration to DAP (Pronaf* Aptitude Declaration) and everything stops because of a missing declaration ( ${ }^{*}$ National Program for the Strengthening of Family Agriculture)

(C3 and FUNPEC workers at a process analysis meeting)

As described above, despite the normative requirement for expedited processing through the various stages, there are excessive delays in approval, documentation and decision making.

Thus, waiting exhibits a damage relationship with the principle of efficiency, since the problems of a cumbersome process cause a public organization to violate this PPA because they generate rework and require lengthy waiting periods until resolution, resulting in financial and academic losses for the institution.

According to Gasparini (2012), these delays require in-depth investigation to identify their causes, since, according to the principle of efficiency, procrastination is never justified.

On the other hand, this process follows the letter of the law. While this waste violates the principle of efficiency, it complies with the PPA of legality. An example is the problem of waiting for documents in order to register the process and proceed with submission. In this case, despite causing flow inefficiency, documentation is required to comply with the legal demands, as stipulated in the principle of legality.

Waiting also has a damage relationship with the PPA of impersonality, since the high visibility of their projects means some researchers attempt to expedite the process to reduce waiting times, as shown in the following statements:

...if you know somebody, it makes it easier. If you don't, you have to wait a long time.

(focus group held with project coordinators)

...The fact is...on one hand you have to comply with the legal requirements.... and on the other certain projects receive preferential treatment over others...

(C3 workers and FUNPEC workers at a process analysis meeting) 
The PPA of publicity is also related to waiting because the slow-moving submission process ultimately hampers publication, thereby violating the principle of publicity.

As demonstrated in Figure 5, defects waste follows this same trend and is related to the principles of legality, morality and efficiency.

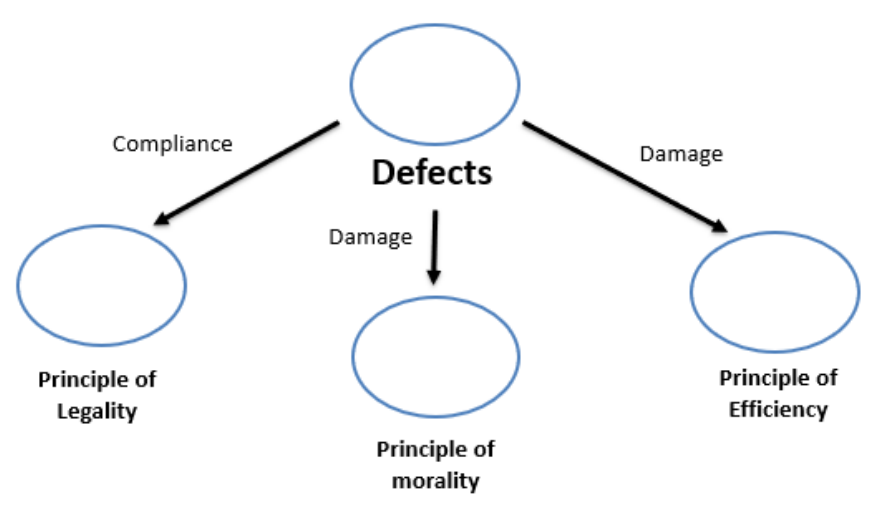

Figure 5. Nodes of the relationship between defect waste and the PPA. Source: Research data (2018).

This type of waste also requires careful investigation because it occurs so often in the process and these errors do not add value, meaning they must be eradicated from the flow. Thus, in addition to improving the process, the principles related to flaws will also be effectively fulfilled (Liker, 2007).

This waste is illustrated in the errors reported by the user-customer of the process, since the information system of the institution only allows registration to continue when a certain document is attached, as described below:

...That's happened to me before with a project l've received. When I looked at the document, there was nothing on it; the applicant said the system wouldn't let them send it without including a document so they attached a blank one...

(C3 workers and FUNPEC workers at a process analysis meeting)

This causes waste in the process due to errors in the inclusion of these documents, which are a legal requirement and necessary for completion of the process. This waste is identified in Financial and Technical Analyses.

With respect to the relation between defects and the principle of legality, the process analyzed is a public administration process that cannot contain errors that interfere in the conditions stipulated under law, that is, the submission process must be duly followed, since it is enshrined in the resolution itself. Therefore, there is a compliance relationship with the PPA.

Defect-related waste is also associated with the PPA of morality, since some of the most frequent process defects observed during the investigation occurred because of mistakes made by civil servants. Thus, defects have a damage relationship with the principle.

With respect to the relationship with the PPA of efficiency, this waste compromises the process and the work dynamic of the sector, generating rework to correct the defects and decreasing process efficiency.

Moreover, unnecessary motion waste is related to the principles of impersonality and efficiency (Figure 6). 


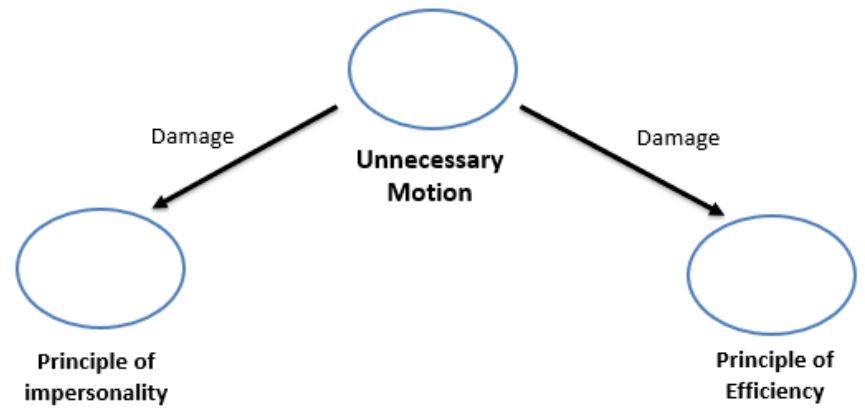

Figure 6. Nodes of the relationship between unnecessary motion waste and the PPA. SOURCE: Research data (2018).

Unnecessary motion occurs with those executing the process and users, since coordinators are instructed via different communication channels, potentially resulting in a lack of information standardization or outdated information, which may cause rework. Moreover, stakeholders enquire about the status of project approval from office of the Vice President via emails and telephone calls, leading to unnecessary motion.

As such, given the lack of judicial knowledge, in some situations stakeholders have to cover significant distances for an informal consultation. Nevertheless, physical processes are received by PROPLAN (faculty of planning), which files it with the coordinator of C3, who then registers and refers the person to the sector in charge, generating unnecessary motion and delaying process completion.

Users move about unnecessarily due to lack of accessible information on process flow. In addition, some users resorted to face-to-face contact with the stakeholders of the process in an attempt to expedite completion. These cases are recognized in the following discourses:

...I'm the same as him, I get the runaround and still get nowhere...

(focus group held with project coordinators)

...Our project is actually moving fairly quickly. It's been 45 days, but I'm here every day, 3 times a day, until it gets approved...

(focus group held with project coordinators)

...It's like the professor said, we don't know where the project stands... SIPAC (Integrated System for Assets, Administration and Contracts) says it's with PROPLAN, but whether it's with technician $A$ or $B$....we really have no idea...

(C3 and FUNPEC workers at a process analysis meeting)

This type of waste is therefore related to the PPA of impersonality, but the relationship is negative because it violates the principle of impersonality when users resort to in-person contact to access information and accelerate the submission process.

If the information were more clearly explained to the interested parties, there would be no need for them to seek help so frequently, but when they ask for information from a particular analyst due to greater affinity or with the expectation of preferred treatment, the principle of impersonality is violated. 
Unnecessary motion is also related to the PPA of efficiency, given that it delays the submission process. Additionally, information has to be relayed to a large number of stakeholders and users, further lengthening the submission process.

These interruptions may provoke an increase in process time because executors are forced to rethink the situations (Batista et al., 2014; McManus, 2005).

Transportation waste is related to the principles of legality and efficiency, as depicted in Figure 7.

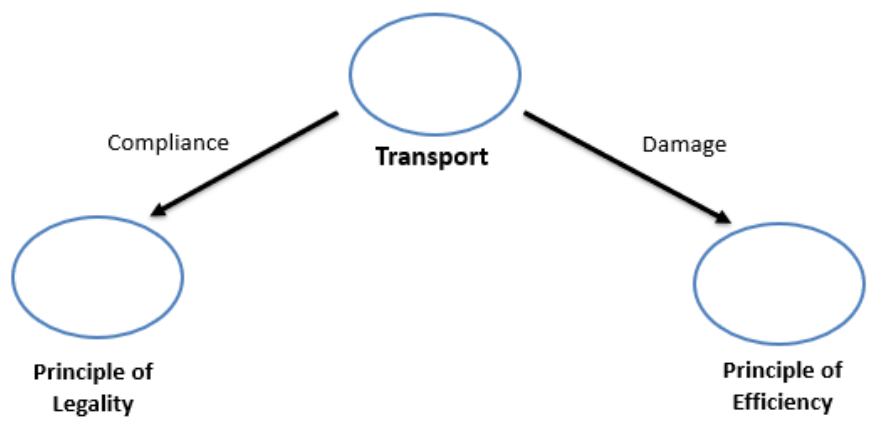

Figure 7. Nodes of the relationship between transport waste and the PPA. Source: Research data (2018).

When the project is registered in SIGAA (Integrated System for the Management of Academic Activities), it is not automatically included in SIPAC, the entity responsible for registering and formalizing the entire academic project submission process. It is important to underscore that despite this lack of integration, both are actually part of a single integrated system. This means the coordinator has to perform the same tasks twice, causing unnecessary motion between the systems, as illustrated in the following statement:

...It was the so-called integrated system. In fact, they're not actually integrated. Nothing happened....the project just died there...

(focus group held with project coordinators)

...Another thing, changing the heading for example....how do I go about it: I have to send a report to the foundation and the foundation sends it to PROPLAN, instead of just being able to do it myself via the system...

(focus group held with project coordinators)

In this case, the problem is related to a number of factors, namely the institutional culture, since sectors generally triangulate information; interinstitutional relationships, which hinder direct access to information; and the lack of integration between systems, forcing users to transport the same information from one system to another, causing redundancy. These cases can also be denominated boundary waste (Batista et al., 2014).

As such, transportation waste is directly related to the PPA of efficiency, when the lack of integration between systems leads to rework and inefficient process flow, thereby contravening the PPA. 
It is also related to the PPA of legality, since there are several sectors involved in the submission process analyzed and frequent transportation is required to comply with the regulations, characterizing a compliance relationship.

Excessive processing was related to the principle of legality and inventory waste to the principle of efficiency (Figure 8), both exhibiting low flow incidence.

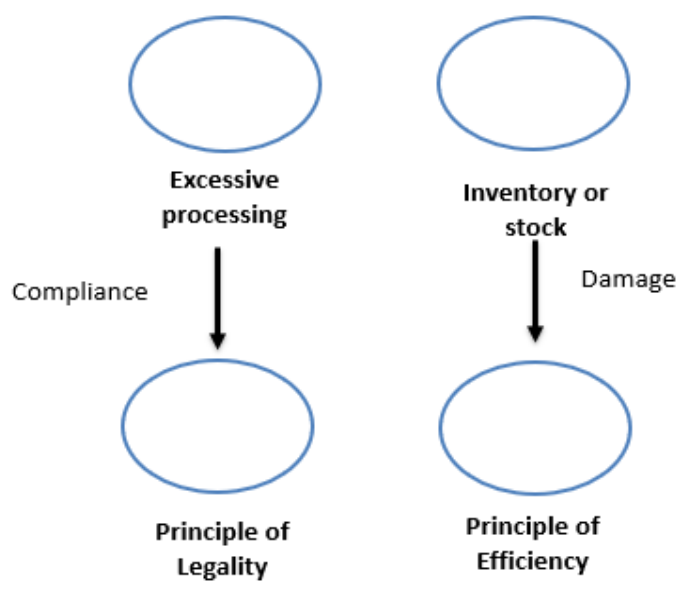

Figure 8. Nodes of the relationship between excessive processing waste, inventory and the PPA. Source: Research data (2018).

Despite being considered waste, excessive processing is necessary in the public sector in order to comply with the legislation. A same process requires multiple phases of approval and management cannot intervene because public administrators must fully comply with the laws in force (Mello, 2011; McManus, 2005). The following transcription illustrates this assertion.

...not to mention the excessive ...bureaucracy and rework. Reports, declarations, approval...

\section{(focus group held with project coordinators)}

An academic contract requires project approval from multiple sources, generating excessive processing. Despite causing delays in process flow, these approvals are stipulated in the resolution that governs academic project submission and therefore comply with the principle of legality.

As such, this lean waste exhibits a compliance relationship with the PPA of legality.

Additionally, each sector/stakeholder in the process has its own control mechanism (Microsoft Excel spreadsheets or Microsoft Word tables), producing excessive information that is not duly investigated due to lack of a single control procedure and information sharing.

This leads to wasted information, which is not managed to improve practices and therefore violates the principle of efficiency. If well applied, this information could help control and manage process flow (McManus, 2005; Liker, 2007).

Overproduction waste is assumed to be related to the principles of efficiency and legality, but there is insufficient evidence to confirm its effects on and relationship with the PPA.

Table 3 presents a summary of the results of the relationships identified between process waste and the PPA. 
Table 3. Relationship between waste and the PPA.

\begin{tabular}{|c|c|c|}
\hline Types of Waste & Number & Related Principles \\
\hline \multirow{4}{*}{ Waiting } & \multirow{4}{*}{16} & - Principle of Legality \\
\hline & & - Principle of Impersonality \\
\hline & & - Principle of Publicity \\
\hline & & Principle of Efficiency \\
\hline \multirow{3}{*}{ Defects } & \multirow{3}{*}{9} & - Principle of Legality \\
\hline & & - Principle of Morality \\
\hline & & Principle of Efficiency \\
\hline \multirow{2}{*}{ Unnecessary Motion } & \multirow{2}{*}{6} & - Principle of Impersonality \\
\hline & & · Principle of Efficiency \\
\hline \multirow{2}{*}{ Transport } & \multirow{2}{*}{2} & - Principle of Legality \\
\hline & & - Principle of Efficiency \\
\hline Excessive Processing & 1 & - Principle of Legality \\
\hline Inventory & 1 & - Principle of Efficiency \\
\hline \multirow{2}{*}{ Overproduction } & \multirow{2}{*}{1} & - Principle of Legality \\
\hline & & Principle of Efficiency \\
\hline
\end{tabular}

Source: Research Data (2018).

Two categories of relationships exist between the wastes and the PPA: a negative (damage) relationship that violates the principles, representing most of the relations observed, and a positive (compliance) relationship, inferring that this supports the scope of the PPA and is directly linked to the principle of legality.

To facilitate visualizing these relationships, waste and principles are treated as 2 interrelated sets of elements, with relationships represented by straight lines that connect one element of a particular set to another of a second set according Figure 9.

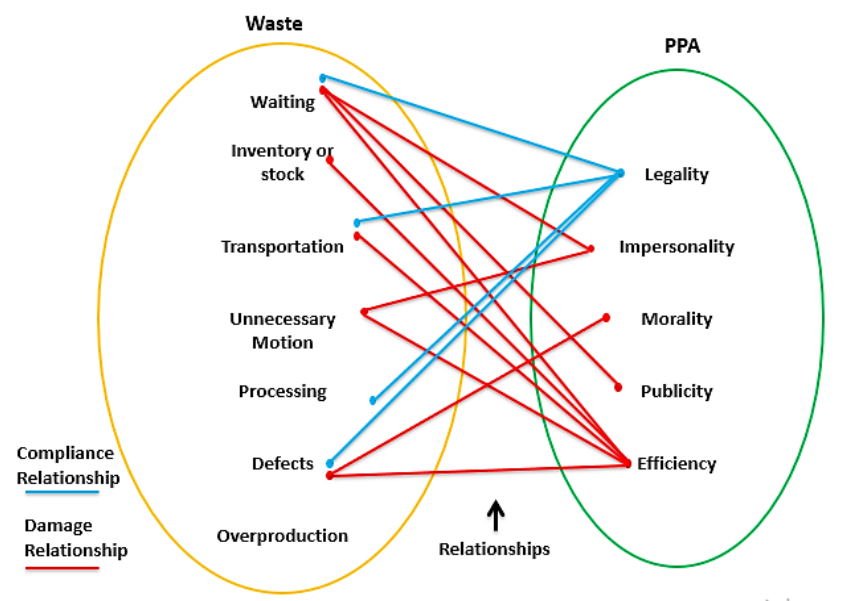

Figure 9. Relationship between waste and the PPA. Source: The authors (2018).

In this respect, our findings show that the fact that some public administration activities must comply with the laws they are bound by results in waste because of the strict norms required to adhere to this principle. 
Waiting-related waste and the principle of efficiency were the most frequent incidents and are directly related to one another. The process is suspended in nearly all the stages of the flow, contravening the principle of efficiency. Moreover, some waiting waste derived from the legal requirements of the process to comply with the principle of legality.

In this respect, in addition to being necessary to comply with the principle of legality, excessive processing is one of the sources of waiting, unnecessary motion and transportation waste because the process must be approved by several departments (waiting), stakeholders need to keep in contact with those in charge of each department (unnecessary motion), and project registration is a mandatory step in the flow process, despite the fact that the systems are not totally integrated (information transportation).

Most statements related to the principle of legality tend to come from the executors of the process, with users typically citing excessive bureaucracy.

Users who submitted highly visible projects believe they deserve preferential treatment. Although this is common and acceptable practice in the private sector, it contravenes the principle of impersonality in the public context because everyone should be treated equally, with those in charge of the process reporting they felt uneasy prioritizing some users over others.

The largest number of problems in terms of identifying waste occurred in technical and financial analysis, indicating the need to pay more attention to these stages.

\section{Conclusion}

The present study aimed at analyzing waste categorized by lean and PPA, in the process flow of a public higher education institution, demonstrating their relationships. In general, the results show that process waste can compromise the principles of public administration, exposing bottlenecks and compliance with PPA in executing the process.

Waste analysis based on PPA is efficient in identifying public process problems, meaning public sector practices and projects can be better planned and target improvements that are in line with the PPA that guide Brazilian public administration.

Study limitations were in the data collection phase. The initial intention was to use participant observation in all sectors related to flow, but there was no demand in the processes for this technique. Seasonality is one of the characteristics of the flow studied. However, this limitation did not hinder the study because participant observation was used in the process analysis meeting, thus achieving the proposed objectives.

Finally, future studies should investigate the impact of interventions in the waste identified in the process flow analyzed and explore the contradiction observed, whereby some waste was beneficial and complied with the principles in executing the process, as well as review waste categorization in public service based on the lean approach.

\section{References}

Abrucio, F. (2010). Construindo uma nova gestão pública. Natal: Searh/RN.

Bardin, L. (2006). Análise de conteúdo (L. A. Rego \& A. Pinheiro, Trads.). Lisboa: Edições 70. Obra original publicada em 1977.

Batista, A. S., Campos, C. A., Renó, G. W. S. T., \& Truzzi, O. M. S. (2014). Melhoria em desempenho em centro de relacionamento com os clientes. Lean Institute Brasil. Retrieved in 2018, April 25, from http://www.lean.org.br/artigos/252/comunidade.aspx 
Bekesas, L. C. (2012). Simulação como ferramenta para aplicação do MFV. (Dissertação de mestrado). Programa de Mestrado em Engenharia de Produção, Centro Universitário Nove de Julho, São Paulo.

Brasil. Constituição. (1988). Constituição da República Federativa do Brasil. Brasília, DF: Senado Federal, Centro Gráfico.

Cole, B. (2011). Lean six-sigma for the public sector: leveraging continuous process improvement to build better governments. Milwaukee: American Society for Quality, Quality Press.

Di Pietro, M. S. Z. (2015). Direito administrativo (28. ed.). São Paulo: Editora Atlas S.A.

Flick, U. (2013). Introdução à metodologia de pesquisa (M. Lopes, Trad. \& D. Silva, revisão técnica). Porto Alegre: .

Gasparini, D. (2012). Direito administrativo. São Paulo: Saraiva.

Gonçalves, V. K. A., De Melo, D. R. A., Viana, Á. L., \& Medeiros, S. H. S. (2015). Lean office: estudo da aplicabilidade do conceito em uma universidade pública federal. Espacios., 18(36), E-1.

Graban, M. (2013). Hospitais lean: melhorando a qualidade, a segurança dos pacientes e o envolvimento dos funcionários (R. Rübenich, Trad.). Porto Alegre: Bookman.

Kadarova, J., \& Demecko, M. (2016). New approaches in lean management. Procedia Economics and Finance, 39, 11-16. Retrieved in 2017, April 20, from www.sciencedirect.com

Landmann, R., Bittencourt, E., Schwitzky, M., \& Wyebski, J. (2009). Lean office: aplicação da mentalidade enxuta em processos administrativos de uma empresa do setor metal mecânico. In Anais do $29^{\circ}$ Encontro Nacional de Engenharia de Produção ENEGEP e ICIEOM (pp. 113). Rio de Janeiro: ABEPRO.

Liker, J. K. (2007). O modelo toyota - a empresa que criou a produção enxuta (Trad. L. B. Ribeiro). Porto Alegre: Bookman.

Lima, O. F., \& Leite, J. P. (2011). Aplicabilidade dos conceitos da produção enxuta (lean production) no processo de licitação pública. In Anais do $36^{\circ}$ Anais do Encontro Nacional de Engenharia de Produção ENEGEP e ICIEOM (pp. 1-14). Rio de Janeiro: ABEPRO.

McManus, H. L. (2005). Product development value stream mapping (PDVSM) Manual. The Lean Aerospace Initiative. Cambridge: Massachusetts Institute of Technology.

Mello, C. A. B. (2011). Curso de direito administrativo (29. ed).. São Paulo: Malheiros Editores Ltda.

Miragem, B. (2013). A nova administração pública e o direito administrativo (2. ed.). Londrina: Revista dos Tribunais.

Ohno, T. (2015). Gestão dos postos de trabalho (H. C. Fontoura, Trad.). Porto Alegre: Bookman.

Paiva, F. G., Jr., Leão, A. L. M. S., \& Mello, S. C. B. (2011). Validade e confiabilidade na pesquisa em administração. Revista de Ciências da Administração, 31(13), 190-209. http://dx.doi.org/10.5007/2175-8077.2011v13n31p190.

Pereira, L. C. B. (1996). Da administração pública burocrática à gerencial. Revista do Serviço Público, 47(1). Retrieved in 2018, April 17, from http://www.bresserpereira.org.br/PPAers/1996/95.AdmPublicaBurocraticaAGerencial.pdf

Pereira, L. C. B. (2010). Administração pública e de empresas: duas coisas muito diferentes. Retrieved in 2017, April 17, from http://www.bresserpereira.org.br/view.asp?cod=4768

Richardson, R. J. (2008). Pesquisa social: métodos e técnicas (3a ed.). São Paulo: Atlas.

Sampieri, R. H., Collado, C. F., \& Lucio, M. D. P. B. (2013). Metodologia de pesquisa (5a ed.). Porto Alegre: Penso.

Santos, I. E. (2016). Manual de métodos e técnicas de pesquisa científica (12a ed.). Rio de Janeiro: Impetus.

Thiollent, M. (2011). Metodologia da pesquisa-ação (18a ed.). São Paulo: Cortez. 
Lean waste analysis...

Turati, R. C., \& Musetti, M. A. (2006). Aplicação dos conceitos de lean office no setor administrativo público. In Anais do XXVI Enegep. Rio de Janeiro: ABEPRO.

Vergara, S. C. (2015). Métodos de pesquisa em administração (6a ed.). São Paulo: Atlas.

Womack, J. P., Jones, D. T., \& Roos, D. (2004). A máquina que mudou o mundo: baseado no estudo do massachusetts institute of technology sobre o futuro do automóvel (I. Korytowski, Trad.). Rio de Janeiro: Elsevier. 